\title{
The effect of the calving season on the Wood's model parameters and characteristics of the lactation curve in Czech Fleckvieh cows
}

Tomáš Kopec ${ }^{1,2}$, Gustav Chládek², Josef Kučera ${ }^{2,3}$, Daniel Falta², Oto Hanuš̌3,4 and Petr Roubal $^{4}$

${ }^{1}$ Czech Fleckvieh Breeders Association, Praha, Czech Republic, ${ }^{2}$ Mendel University in Brno, Brno, Czech Republic, ${ }^{3}$ Research Institute for Cattle Breeding Ltd., Vikýřovice, Czech Republic, ${ }^{4}$ Dairy Research Institute Ltd, Praha, Praha 6, Czech Republic

\section{Abstract}

The aim of this study was to determine the effect of a calving season on the Wood's model parameters of the lactation curve and its characteristics in Czech Fleckvieh cows.

The observed Czech Fleckvieh cows (with minimum of $75 \%$ of Czech Fleckvieh breed in the genotype) born between 1994-2007 formed three parity groups: parity 1 with 350853 cows, parity 2 with 269276 cows and parity 3 with 175029 cows. All the parity groups were further classified by the calving season: winter (December-February), spring (March-May), summer (June-August) and autumn (September-November). The Wood's function parameters $(a, b, c)$ were calculated and the lactation characteristics estimated were: partial milk yields per 1-100 days, 100-200 days and a total milk yield of 305 days, the peak yield - amount and day, index of persistency $2: 1$ and a coefficient of the declination rate of the lactation curve. The calving season significantly affected the parameters $(a, b, c)$ of the lactation curve, the persistency of lactation and the number of days-in-milk at peak yield; it had no significant effect on the other characteristics. In general, the cows which calved in winter and autumn had more persistent lactations, regardless of the number of lactation. The first-parity cows reached the peak yield sooner when they calved in summer, the older cows in summer and autumn.

Keywords: cow, Czech Fleckvieh, milk yield, lactation curve, persistence

Abbreviations: IP: index of persistency

Archiv Tierzucht 56 (2013) 80, 808-815

doi: $10.7482 / 0003-9438-56-080$

Corresponding author:

Tomáš Kopec; email: kopec@cestr.cz

Faculty of Agronomy, Mendel University in Brno, Zemědělská 1, 61300 Brno, Czech Republic

() 2013 by the authors; licensee Leibniz Institute for Farm Animal Biology (FBN), Dummerstorf, Germany. This is an Open Access article distributed under the terms and conditions of the Creative Commons Attribution 3.0 License (http://creativecommons.org/licenses/by/3.0/).
Received: 16 December 2012 Accepted: 18 June 2013 Online: 18 June 2013 


\section{Introduction}

The shape of lactation curve and effects influenced on the lactation curve were analysed by Gaskins et al. (1980), Silvestre et al. (2006), Atashi et al. (2012), Boujenane \& Hilal (2012). Atashi et al. (2009) described the effect of the calving season on lactation. A number of mathematical models and methodical techniques were designed to explain the shape of the lactation curve. One of the most frequently used mathematical models is the Wood's model (Wood 1967). It is appreciated for its simplicity and accuracy of the lactation curve description. It is used worldwide by animal scientists to describe the lactation curves in cattle and other farm animals (e.g. Cankaya et al. 2011). The parameters of the Wood's function define the shape of the lactation curve and estimate the milk yield in a particular stage of lactation and thus the persistency index of lactation. Koçak et al. (2008) or Grzesiak et al. (2003) compared several mathematical models of the lactation curve.

Haile-Mariam \& Goddard (2008) or Jamrozik et al. (1997) used the random regression test-day model for describing the lactation curve and for estimating genetic parameters of lactations. Swalve \& Guo (1999) compared the variation of lactation curves stratified by herd, lactation number and total milk yield. The results showed difficulties of differentiation of cows into groups according to total milk yield. Kawonga et al. (2012) used Wood's model, critical exponential and double exponential model for describing lactation curve for breeding management of smallholders' dairy farms.

Many authors pointed to the influence of calving season on milk traits (e.g. Řehák et al. 2012, Ray et al. 1992). The goal of this paper was to determine the effect of a calving season on the shape of lactation curve and its characteristics in Czech Fleckvieh cows. Wood's model was used for describing the shape of lactation curve. Třináctý et al. (1991) described the lactation curve in Czech Fleckvieh cows by Wood's model.

\section{Material and methods}

The observed Czech Fleckvieh cows (with the minimum of $75 \%$ of Czech Fleckvieh breed in the genotype) born between 1994-2007 formed three parity groups: parity 1 with 350853 cows, parity 2 with 269276 cows and parity 3 with 175029 cows. The cows lactated for a minimum of 240 and a maximum of 360 days and were tested (milk-recording) at least six times in the course of lactation. All the parity groups were further classified by the calving season (see Table 1).

The Wood's function parameters $(a, b, c)$ were calculated and the lactation characteristics estimated: milk yield per 1-100 days, 100-200 days and 305 days, index of persistency (IP) 2:1, the peak yield - amount and day, the coefficient of the declination rate.

Table 2 (Fathi Nasri et al. 2008) shows some parameters of the lactation curve: $t$-days at the peak yield, $y_{m}$-peak milk yield, $r$-a coefficient describing the degree of declination between the peak and the end of the lactation, $a, b, c$-estimated parameters of the Wood's model. These parameters determined the shapes of lactation curves for the parity groups 1, 2 and 3, with respect to the calving season; the total and partial (305 days, 1-100 days and 100-200 days) milk yields were calculated. The partial milk yields determined the index of persistency of lactation

$$
I P=\frac{100-200 \text { days yield }}{1-100 \text { days yield }} \times 100
$$


The applied Wood's mathematical model was as follows:

$$
y=a t^{b} e^{-c t}
$$

where $a, b, c$-are the estimated parameters of the function, $y$ is the milk yield on the test day $(\mathrm{kg}), t$ is the test day and $e$ is the base of the natural logarithm. The Wood's model parameters were estimated by a procedure PROC NLIN in SAS v9.1 (SAS Institute Inc., Cary, NC, USA). The effect of the calving season on the lactation curve characteristics was tested by the analysis of variance procedure of PROC ANOVA in SAS v9.1.

Table 1

Numbers of cows and their classification by parity and calving season

\begin{tabular}{llll}
\hline Parity & Calving season & Month of calving & Number \\
\hline 1 & Winter & December-February & 94104 \\
& Spring & March-May & 89465 \\
& Summer & June-August & 83207 \\
2 & Autumn & September-November & 84077 \\
& Winter & December-February & 72808 \\
& Spring & March-May & 68796 \\
& Summer & June-August & 64661 \\
& Autumn & September-November & 63107 \\
& Winter & December-February & 46554 \\
& Spring & March-May & 43671 \\
& Summer & June-August & 43177 \\
\end{tabular}

Table 2

The estimation of some characteristics of the lactation curve

\begin{tabular}{ll}
\hline Parameter & Formula \\
\hline $\mathrm{t}$ & $\mathrm{b} / \mathrm{c}$ \\
$\mathrm{y}_{\mathrm{m}}$ & $\mathrm{a}(\mathrm{b} / \mathrm{c})^{\mathrm{b}} \mathrm{e}^{-\mathrm{b}}$ \\
$\mathrm{r}$ & $\mathrm{b} /((\mathrm{t}+305) / 2)-\mathrm{c}$ \\
\hline
\end{tabular}

\section{Results and discussion}

The parameters and the peak yield day varied significantly in the observed calving seasons in all lactations (Table 3 and 4). On the contrary, cows in all lactations produced a similar amount of milk at peak, regardless of the calving season.

The first-parity cows which calved in summer had the greatest $a$ parameter and smallest $b$ and $c$ parameters. They reached the peak milk yield faster than the other groups-in 38 days. These values indicate that the summer-calvers produce more milk at the onset of lactation and come to the peak earlier. At the same time, the declination of milk production is slower ( $r$ value) which means a better persistency of lactation compared to the winter and spring calvers. Figures 1, 2 and 3 show the lactation curves of cows in lactation 1, 2 and 3.

The Wood's model parameters and t values varied between calving seasons in lactations 2 and 3 . Summer and autumn calvers had significantly lower $t, b$ and $c$ values and a higher 
Table 3

Wood's model parameters $(a, b, c)$, peak milk yield $(y m)$, days in milk at peak $(t)$ and the coefficient of a declination rate $(r)$

\begin{tabular}{lllllllll}
\hline Parity & Season & Number & $\mathrm{a}$ & $\mathrm{b}$ & $\mathrm{c}$ & $\mathrm{t}$ & $\mathrm{ym}$ & $\mathrm{r}$ \\
\hline 1 & Winter & 94104 & $12.2002^{\mathrm{b}}$ & $0.1779^{\mathrm{a}}$ & $0.0036^{\mathrm{a}}$ & $49.56^{\mathrm{a}}$ & 20.76 & $-0.00260385^{\mathrm{a}}$ \\
& Spring & 89465 & $13.1649^{\mathrm{a}}$ & $0.1648^{\mathrm{a}}$ & $0.0037^{\mathrm{a}}$ & $44.94^{\mathrm{a}}$ & 21.10 & $-0.00280385^{\mathrm{a}}$ \\
& Summer & 83207 & $15.1987^{\mathrm{c}}$ & $0.1035^{\mathrm{b}}$ & $0.0028^{\mathrm{b}}$ & $37.82^{\mathrm{b}}$ & 20.34 & $-0.00218654^{\mathrm{b}}$ \\
& Autumn & 84077 & $13.8365^{\mathrm{a}}$ & $0.1253^{\mathrm{c}}$ & $0.0028^{\mathrm{b}}$ & $44.38^{\mathrm{a}}$ & 20.20 & $-0.00208846^{\mathrm{b}}$ \\
& Winter & 72808 & $16.2276^{\mathrm{a}}$ & $0.1734^{\mathrm{a}}$ & $0.0048^{\mathrm{a}}$ & $36.37^{\mathrm{a}}$ & 25.90 & $-0.00376538^{\mathrm{a}}$ \\
& Spring & 68796 & $16.3558^{\mathrm{a}}$ & $0.1868^{\mathrm{a}}$ & $0.0053^{\mathrm{b}}$ & $35.48^{\mathrm{a}}$ & 26.67 & $-0.00421923^{\mathrm{b}}$ \\
& Summer & 64661 & $18.9978^{\mathrm{b}}$ & $0.1239^{\mathrm{b}}$ & $0.0043^{\mathrm{c}}$ & $28.82^{\mathrm{b}}$ & 25.82 & $-0.00360577^{\mathrm{a}}$ \\
& Autumn & 63107 & $18.5441^{\mathrm{b}}$ & $0.1201^{\mathrm{b}}$ & $0.0040^{\mathrm{d}}$ & $29.95^{\mathrm{b}}$ & 25.27 & $-0.00328269^{\mathrm{c}}$ \\
& Winter & 46554 & $15.7457^{\mathrm{a}}$ & $0.1986^{\mathrm{a}}$ & $0.0053^{\mathrm{a}}$ & $37.33^{\mathrm{a}}$ & 26.91 & $-0.00417692^{\mathrm{a}}$ \\
& Spring & 43671 & $15.4909^{\mathrm{a}}$ & $0.2189^{\mathrm{b}}$ & $0.0060^{\mathrm{b}}$ & $36.96^{\mathrm{a}}$ & 27.67 & $-0.00468654^{\mathrm{b}}$ \\
& Summer & 43177 & $18.1806^{\mathrm{b}}$ & $0.1534^{\mathrm{c}}$ & $0.0050^{\mathrm{c}}$ & $31.08^{\mathrm{b}}$ & 26.78 & $-0.00408654^{\mathrm{a}}$ \\
& Autumn & 41627 & $18.5928^{\mathrm{b}}$ & $0.1358^{\mathrm{d}}$ & $0.0045^{\mathrm{d}}$ & $30.43^{\mathrm{b}}$ & 26.30 & $-0.00368269^{\mathrm{c}}$ \\
\hline
\end{tabular}

Within a parity $(1,2,3)$, values marked with different superscripts $\left({ }^{(a, b, c, d}\right)$ differ $(P<0.05)$.

Table 4

Wood's model estimations of the total (305-d) and partial (1-100 and 100-200 days) milk yield and the persistency of lactation index (IP 2:1)

\begin{tabular}{lllclcc}
\hline Parity & Season & Number & 305-d milk yield, kg & IP 2:1 & 1-100 yield, kg & 100-200 yield, kg \\
\hline 1 & Winter & 94104 & 5161.00 & $88.79^{\mathrm{a}}$ & 1972.18 & 1766.67 \\
& Spring & 89465 & 5149.20 & $86.23^{\mathrm{b}}$ & 2009.61 & 1751.30 \\
& Summer & 83207 & 5125.50 & 87.28 & 1951.58 & 1722.58 \\
& Autumn & 84077 & 5151.60 & $89.71^{\mathrm{a}}$ & 1926.05 & 1744.97 \\
& Winter & 72808 & 5758.30 & $78.80^{\mathrm{a}}$ & 2439.57 & 1938.92 \\
& Spring & 68796 & 5735.30 & $76.18^{\mathrm{b}}$ & 2499.74 & 1922.77 \\
& Summer & 64661 & 5696.10 & 77.00 & 2429.19 & 1890.82 \\
& Autumn & 63107 & 5731.10 & $79.24^{\mathrm{a}}$ & 2388.07 & 1911.08 \\
& Winter & 46554 & 5821.90 & $77.16^{\mathrm{a}}$ & 2520.30 & 1962.20 \\
& Spring & 43671 & 5779.60 & $74.59^{\mathrm{b}}$ & 2576.07 & 1940.88 \\
& Summer & 43177 & 5735.30 & 75.22 & 2506.31 & 1906.93 \\
& Autumn & 41627 & 5792.80 & $77.20^{\mathrm{a}}$ & 2473.19 & 1929.43 \\
\hline
\end{tabular}

Within a parity $(1,2,3)$, values marked with different superscripts $(a, b, c, d)$ differ $(P<0.05)$.

$a$ value. They reached the peak yield early and the amount of milk was slightly (nonsignificantly) lower.

Macciotta et al. (2005) estimated Wood's model parameters for Fleckvieh cows in Italy. They analysed the data over the period from 1989-2002 and determined parameters $a$ (11.36), $b$ (0.267) and c (-0.00564). Třináctý et al. (1990) estimated the parameters for Czech Fleckvieh cows: $a$ (12.74), $b$ (0.143) and c (0.0046). Dematawewa et $a l$. (2007) assessed lactation curves in Holstein cows born between 1997-2003 with the following parameters: $a(15.6862), b(0.2081)$ and $c$ (0.002). Gołębiewski et al. (2011) calculated the parameters in Montbeliarde cows: $a$ (28.44), $b$ (0.24) and c (-0.13). Macciotta et al. (2005), Třináctý et al. (1990) and Dematawewa et al. (2007) presented lower values of the parameters, while Gołębiewski et al. (2011) found higher values (except for $c$ ). 


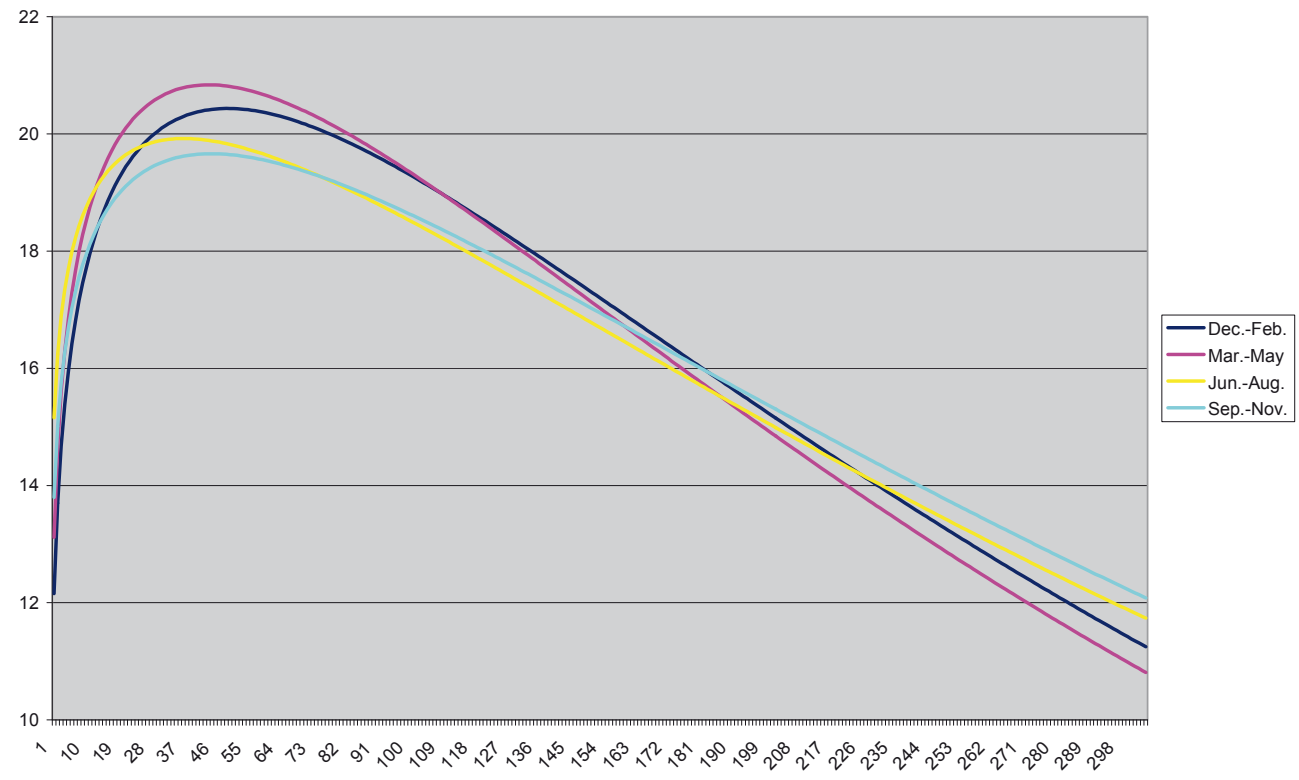

Figure 1

Lactation curves with respect to the calving season - parity 1 (axis $\mathrm{y}$ : $\mathrm{kg}$ of milk, axis $\mathrm{x}$ : days in milk)

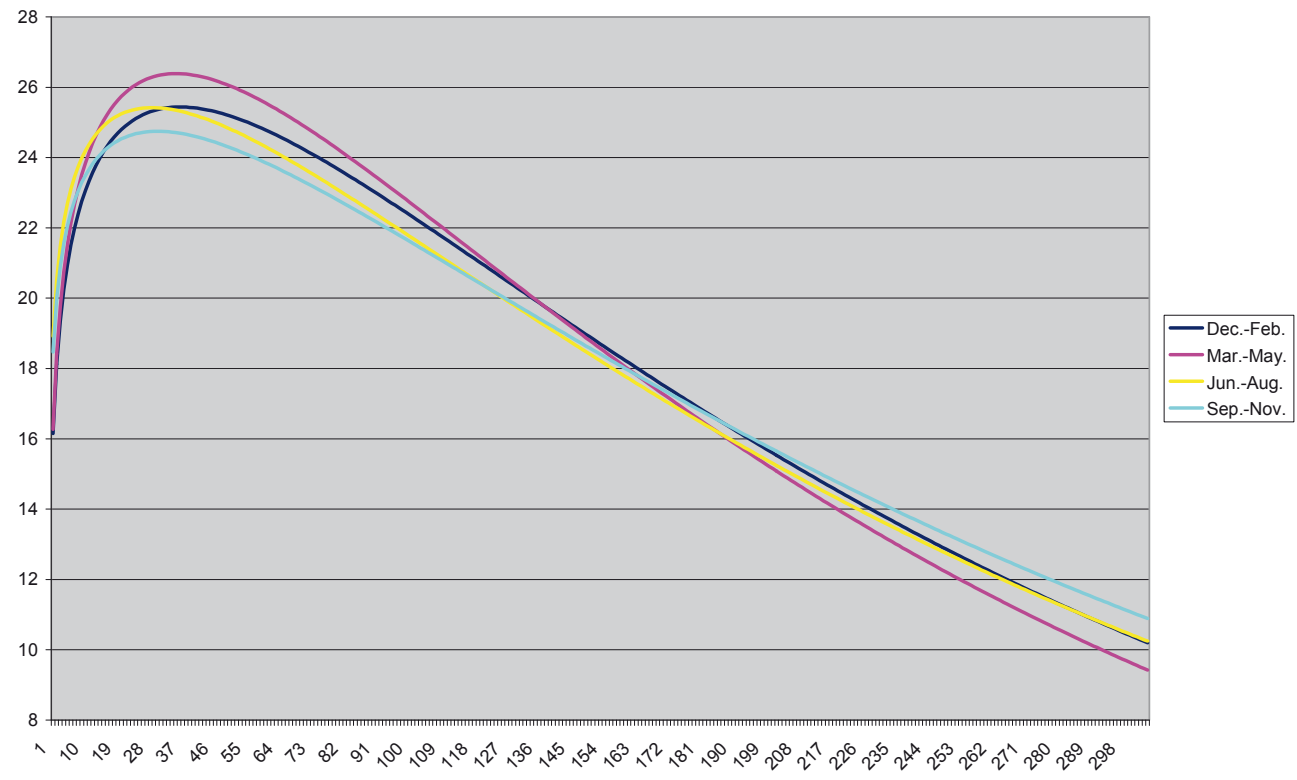

Figure 2

Lactation curves with respect to the calving season - parity 2 (axis $\mathrm{y}: \mathrm{kg}$ of milk, axis $\mathrm{x}$ : days in milk) 


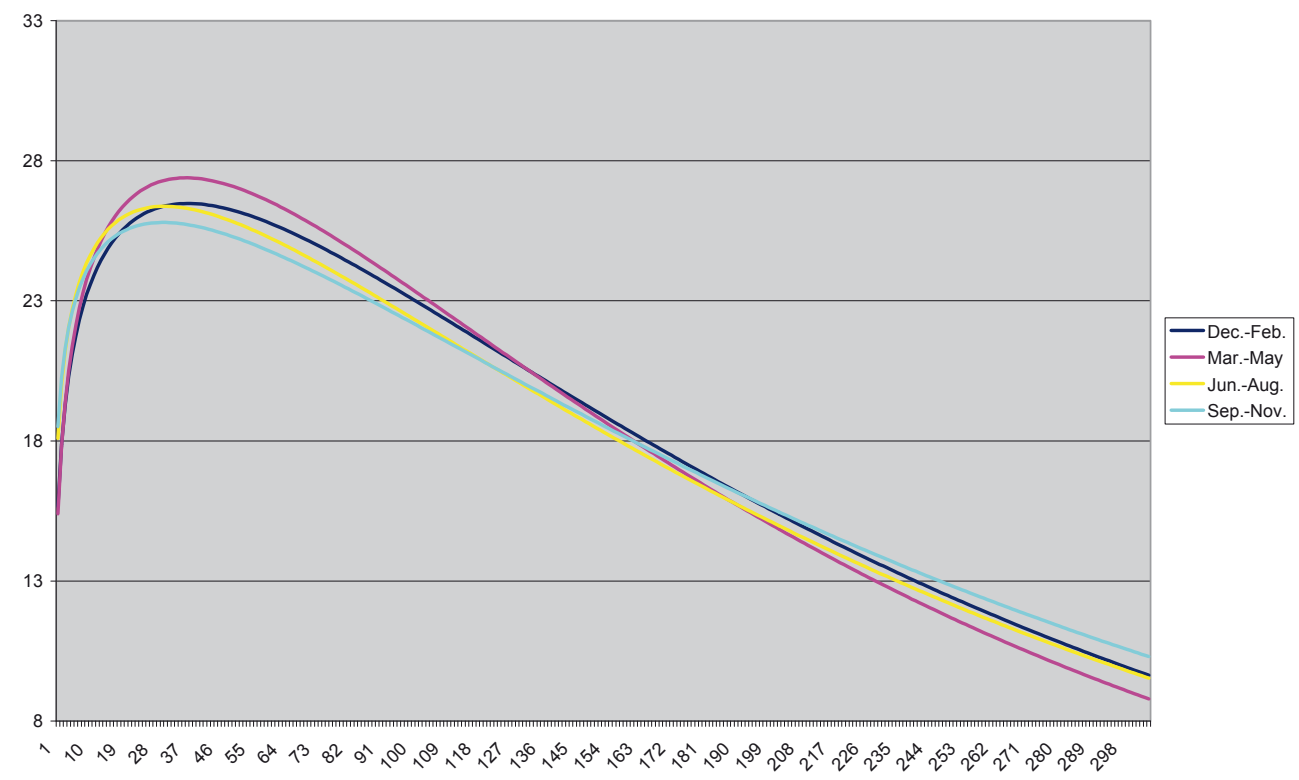

Figure 3

Lactation curves with respect to the calving season - parity 3 (axis $\mathrm{y}$ : $\mathrm{kg}$ of milk, axis $\mathrm{x}$ : days in milk)

Fathi Nasri et al. (2008) observed that the first-parity cows reached the peak yield of $33.6 \mathrm{~kg} 63$ days post-partum, the second-parity cows achieve the climax of $39.5 \mathrm{~kg} 46$ days post-partum and the third-parity cows produced a maximum of $41.8 \mathrm{~kg}$ of milk 42 days post-partum. Similarly to Fathi Nasri et al. (2008), we also found that later-parity cows reached maximum sooner and produced more milk at peak than younger cows. In the study of Dematawewa et al. (2007) cows produced a maximum of $33.35 \mathrm{~kg}$ milk 102 days post-partum.

Table 4 presents an estimated 305 days milk yield and partial yields per 1-100 days and 100-200 days. The persistency of lactation index IP 2:1 was calculated. Only the IP 2:1 significantly varied between calving seasons in all parity groups. Autumn and winter calvers had a significantly greater IP 2:1 than spring calvers; the IP 2:1 in summer calvers did not differ from the rest in all parity groups. A calving season did not significantly affect either the partial or total milk production. Třináctý et al. (1990) calculated the IP 2:1 between 74.2 and 77.2, regardless of the number of lactation, which is slightly lower than our values (Table 4). Fathi Nasri et al. (2008) estimated the 305 days milk production at $8068 \mathrm{~kg}$ (lactation 1), $9233 \mathrm{~kg}$ (lactation 2) and $9323 \mathrm{~kg}$ (lactation 3) in Holstein cattle population in Iran. The similar issue in population of Iranian Holstein was studied by Roshanfekr et al. (2010).

Neither milk yield per day nor the total or partial milk yields significantly differed between calving seasons in all parity groups. The maximum yield was higher in older cows (lactation 2 and 3). The same results were observed in case of the total and partial milk yields. The total milk production in the first lactation ranged between 5125 and $5161 \mathrm{~kg}$, in later lactations between 5696 and $5821 \mathrm{~kg}$ milk per 305 days. 
The lactation was more persistent in younger cows (the first parity, IP 2:1 86.23-89.71) compared to older ones (the second and the third parity, IP 2:1 74.59-79.24). First-calvers also produced less milk (maximum, partial and total yield) and reached the peak later (38-50 days) than older cows (peak 28-37 days).

Our results demonstrated the effect of a calving season on the shape of the lactation curve, especially on the day of the peak yield, the index of persistency and the declination rate. On the other hand, the milk yield, whether peak, partial or total, was not affected by the calving season. The assessed parameters and the shapes of the lactation curves revealed the differences between younger (the 1st parity) and older (the second and the third parity) cows.

The lactations of the autumn- and winter-calvers were significantly more persistent than those of spring-calvers. The first-parity cows which calved in summer had different Wood's model parameters and were the fastest to reach the peak. Older cows (the second and the third parity) which calved in summer and autumn had a significantly smaller $t$ and different $a, b, c$ compared to the cows which calved in winter and spring.

In general, the cows which calved in winter and autumn had more persistent lactations, regardless of the parity. The first-parity cows reached the peak yield sooner when they calved in summer, the older cows in summer and autumn. The results showed the influence of calving season on the shape of lactation curve, particularly peak yield and index of persistency was influenced by calving season. This factor should be considered comparing lactation parameters of cows calved in different seasons.

\section{Acknowledgements}

The study was supported by MSM 6215648905, KONTAKT ME 09081, R00511 from February 28th 2011 and IGA TP 2/2013 FA, MENDELU.

\section{References}

Atashi H, Sharbabak MM, Sharbabak HM (2009) Environmental factors affecting the shape components of the lactation curves in Holstein dairy cattle of Iran. Livest Res Rural Dev 21, 5

Atashi H, Zamiri MJ, Sayyadnejad MB (2012) Effect of twinning and stillbirth on the shape of lactation curve in Holstein dairy cows of Iran. Arch Tierz 55, 226-233

Boujenane I, Hilal B (2012) Genetic and non genetic effects for lactation curve traits in Holstein-Friesian cows. Arch Tierz 55, 450-457

Cankaya S, Unalan A, Soydan E (2011) Selection of a mathematical model to describe the lactation curves of Jersey cattle. Arch Tierz 54, 27-35

Dematawewa CMB, Pearson RE, VanRaden PM (2007) Modeling Extended Lactations of Holsteins. J Dairy Sci 90, 3924-3936

Fathi Nasri MH, France J, Odongo NE, Lopez S, Bannink A, Kebreab E (2008) Modelling the lactation curve of dairy cows using the differentials of growth functions. J Agric Sci 146, 633-641

Gaskins CT, Anderson DC (1980) Comparison of Lactation Curves in Angus-Hereford, Jersey-Angus and Simmental-Angus Cows. J Anim Sci 50, 828-832

Gołębiewski M, Brzozowski P, Gołębiewski L (2011) Analysis of lactation curves, milk constituents, somatic cell count and urea in milk of cows by the mathematical model of Wood. Acta Vet Brno 80, 73-80 
Grzesiak W, Wojcik J, Binerowska B (2003) Prediction of 305-day first lactation milk yield in cows with selected regression models. Arch Tierz 46, 215-226

Haile-Mariam M, Goddard ME (2008) Genetic and phenotypic parameters of lactations longer than 305 days (extended lactations). Animal 2, 325-335

Jamrozik J, Schaeffer LR, Dekkers JCM (1997) Genetic Evaluation of Dairy Cattle Using Test Day Yields and Random Regression Model. J Dairy Sci 80, 1217-1226

Kawonga BS, Chagunda MGG, Gondwe TN, Gondwe SR, Banda JW (2012) Use of lactation models to develop a cow performance monitoring tool in smallholder dairy farms. Arch Tierz 55, 427-437

Koçak Ö, Ekiz B (2008) Comparison of different lactation curve models in Holstein cows raised on a farm in the south-eastern Anatolia region. Arch Tierz 51, 329-337

Macciotta NPP, Vicario D, Cappio-Borlino A (2005) Detection of Different Shapes of Lactation Curve for Milk Yield in Dairy Cattle by Empirical Mathematical Models. J Dairy Sci 88, 1178-1191

Ray DE, Halbach TJ, Armstrong DV (1992) Season and Lactation Number Effects on Milk Production and Reproduction of Dairy Cattle in Arizona. J Dairy Sci 75, 2976-2983

Řehák D, Volek J, Bartoň L, Vodková Z, Kubešová M, Rajmon R (2012) Relationships among milk yield, body weight, and reproduction in Holstein and Czech Fleckvieh cows. Czech J Anim Sci 57, 274-282

Roshanfekr H, Mamouei M, Yarinejad F, Mohammadi K (2010) Phenotypic study of lactation curve in Iranian Holsteins. J Anim Vet Adv 9, 721-725

Silvestre AM, Petim-Batista F, Colaco J (2006) The accuracy of seven mathematical functions in modelling dairy cattle lactation curves based on test-day records from varying sample schemes. Journal of Dairy Science 89, 1813-1821

Swalve HH, Guo Z (1999) An illustration of lactation curves stratified by lactation yields within herd. Arch Tierz $42,515-525$

Třináctý J, Babák V, Čermák V, Sommerová H (1990) [The shape of the lactation curve in dairy cows of different breeds]. Sborník Vědeckých Prací VúVZ Pohořelice 23, 15-23 [in Czech]

Třináctý J, Babák V, Čermák V, Sommerová H (1991) Determination of parameters of the mathematical model of lactation curves of dairy cows for various performance, breed and order of lactation. Sborník vědeckých prací VúVZ Pohořelice 24, 61-70

Wood PDP (1967) Algebraic Model of the Lactation Curve in Cattle. Nature 216, 164-165 